\title{
Application of the Ultrafiltration and Photooxidation Process for the Treatment of Rainwater
}

\author{
Anna Marszałek $\cdot$ Mariusz Dudziak
}

Received: 3 September 2021 / Accepted: 1 December 2021 / Published online: 7 December 2021

(C) The Author(s) 2021

\begin{abstract}
As water resources become increasingly scarce, the concept of water reuse is gaining importance. Recently, attention has been paid to the use of rainwater as an alternative water resource. Part of this study, laboratory-scale experiments were conducted to evaluate the effectiveness and efficiency of the ultrafiltration process. The aim of the research was to assess the influence of pollutants from various roof coverings on the ultrafiltration process and the occurrence of membrane fouling. Additionally, the rainwater disinfection process was performed using UV radiation. Analysis of rainwater collected from various roofing materials, evaluating rainwater treatment by ultrafiltration in a cross-flow system, determination of the effectiveness and efficiency of the UF membrane, and additional disinfection of rainwater using UV radiation were carried out. Rainwater was collected from various roofing materials, such as steel roof tiles (RW1), bituminous shingles (RW2), and tar paper roofing (RW3). The treatment efficiency of ultrafiltration was evaluated by monitoring typical quality parameters: color, turbidity, COD, TOC, absorbance of UV254, ammonium, conductivity, and $\mathrm{pH}$. Coliform bacteria, Escherichia coli and Enterococci, were monitored as total number of microorganisms at $22 \pm 2{ }^{\circ} \mathrm{C}$ after
\end{abstract}

\section{A. Marszałek $(\bowtie) \cdot$ M. Dudziak}

Department of Energy and Environmental Engineering,

Silesian University of Technology, Konarskiego 18,

44-100 Gliwice, Poland

e-mail: anna.marszalek@polsl.pl
$72 \mathrm{~h}$. As expected, a significant reduction in individual parameters was recorded. COD of rainwater decreased in RW1 by $59 \%$, in RW 2 by $69 \%$, and in RW3 by $74 \%$. The ultrafiltration process ensured the complete retention of the coliform bacteria and E. coli. Complete elimination of microorganisms was demonstrated when the ultrafiltration process and UV radiation disinfection were combined.

Keywords Rainwater - Ultrafiltration · Fouling membrane $\cdot$ Photooxidation

\section{Introduction}

As water resources become increasingly scarce, the concept of water reuse is gaining importance. Recently, attention has been paid to the use of rainwater as an alternative water resource. The most serious concern about collected rainwater is the presence of pathogenic microorganisms, in particular bacteria in the fecal droppings of animals. The collected rainwater can pose a risk to human health if consumed untreated. One solution is ultrafiltration and UV disinfection. Ultrafiltration can both support and improve the process of water disinfection due to the fact that the membrane is a barrier to viruses, bacteria, and protozoa (Bodzek et al., 2019). UV-C lamps are used as germicidal lamps; thus, they are one of the most effective methods of disinfection. The wavelength emitted by these lamps irreversibly inactivates 
bacteria, viruses, mold, fungi, and other microorganisms. They are used wherever it is important to thoroughly disinfect surfaces, air, or water (Li et al., 2019). Rainwater pretreated by a suitable method has many advantages: domestic animals prefer water without calcium and chlorine; reduced use of laundry detergent (water hardness increases the consumption of detergents); and reduces costs for drinking water, wastewater, and garden irrigation. The pretreated rainwater can be used for non-potable purposes such as flushing the toilet, garden irrigation, and pavement cleaning, as well as for direct contact activities such as bathing and washing clothes (Pavolová et al., 2019). According to the new Water Law of January 1, 2018, rainwater in Poland is no longer classified as wastewater; currently, it is defined as water resulting from precipitation (The Act of 18 July 2001 - "Water Law" (Acts. Laws of 2005No. 130,item. 1087) 2001).

The quality of rainwater collected from a roof is influenced by many factors. The composition of rainwater can be contaminated with suspended solids, heavy metals, hydrocarbons, pesticides, and many other substances. Tests of rainwater show high concentrations of physicochemical and bacteriological pollutants. Rainwater collected from a roof may contain contaminants from bird or animal feces, which may pose a risk to water users. Different roofing materials can affect the survival of these bacteria on the roof (Evans et al., 2006). Rainwater is contaminated even by contact with air itself. The results of studies by Evans et al. (Evans et al., 2006) indicated that airborne microorganisms had a significant share in the bacterial load of rainwater from the roof, that the total pollution load was influenced by wind speed, and that the concentration of pollutants changed with the direction of the wind. Other factors influencing the quality of rainwater include, among others, the intensity and duration of precipitation and the type and condition of the material from which the roof is made. The specific location of the roof is very important (Zhang et al., 2014). Zhang et al. (Zhang et al., 2014) found that the quality of the collected rainwater depends on both the type of roof and the environmental conditions. After comparing rainwater collected from four roofs, it was found that a ceramic tile roof is the most suitable for rainwater harvesting applications due to the lowest average concentration of measured water quality parameters. Mendez et al. (Mendez et al., 2011) believe that metal roofs are widely recommended for rainwater collection applications, and studies have shown that rainwater collected from metal roofs tends to have a lower concentration of indicator bacteria in the feces compared to other roofing materials. However, concrete roof tiles and cool roofs produced rainwater of a quality similar to that of metal roofs, indicating that these roofing materials are also suitable for rainwater collection applications.

As part of this study, laboratory-scale experiments were performed to evaluate the effectiveness and efficiency of the ultrafiltration process to purify rainwater. Generally, due to the risk of contamination by microorganisms and organic compounds, rainwater requires some kind of treatment prior to its use. The level of treatment employed depends mainly on the intended use (whether potable or not) and the quality of rainwater collected from roofs or other surfaces (Ahmed et al., 2019; Alim et al., 2020; 2021; Liu et al., 2021). As membrane processes can be easily scaled up, they have been recognized as an attractive alternative to rainwater treatment. However, as it is well known, these processes are accompanied by the inherent phenomena contributing to the reduction of the membrane performance due to the increase of filtration system resistance, especially in the case of porous polymer membranes, this is, microfiltration and ultrafiltration membranes. They include the fouling phenomenon. Therefore, it is also necessary to check the efficiency of the ultrafiltration process. Additionally, the occurring microbiological contamination of rainwater requires the association of membrane processes with another process, in this case UV radiation.

\section{Materials and Methods}

\subsection{Rainwater}

Rainwater was collected from various roofing materials in Poland in Silesia, including steel roof tiles (RW1), bituminous shingles (RW2), and tar paper (RW3). The metal roofing was made of sheets of galvanized steel. Rainwater from the tar roof came from a building located in the vicinity of car garages. 
Other rainwater came from settlements located near the city center. Bituminous shingle is a modern version of roofing felt. It usually consists of five layers with a glass fiber veil placed in the center. Sometimes these shingles also include mineral fillers and modifiers. Subsequently, asphalt (bitumen) is applied on both sides. For protection against the sun, the outer layer consists of a coarse sprinkle. Tar paper consists of many layers, i.e., anhydrous foil, asphalt, a matrix, e.g., of polyester non-woven fabric or glass fabric, and mineral sprinkle.

Rainwater was collected in April and May. The atmospheric dust concentration during this period was $30 \mu \mathrm{g} / \mathrm{m}^{3}$; total precipitation was $46 \mathrm{~mm}$. The physicochemical analysis of rainwater is summarized in Table 1.

\subsection{Quality Analysis and Microbiological Assessment}

Treatment efficiency was evaluated by monitoring typical quality parameters (color, turbidity, COD, TOC, conductivity, $\mathrm{pH}$ ). Color and turbidity measurements were performed with a UV-Vis Spectroquant ${ }^{\circledR}$ Pharo 300 (Merck, Kenilworth, NJ, USA). $\mathrm{COD}$, nitrogen, phosphate, and ammonium concentrations were determined spectrophotometrically with Merck test kits. TOC was measured using a TOC-L series analyzer (Shimadzu, Kyoto, Kyoto Prefecture, Japan). $\mathrm{pH}$ and conductivity were monitored by a multifunctional analyzer CX-461 (Elmetron, Zabrze,

Table 1 The physicochemical analysis of rainwater

\begin{tabular}{lllll}
\hline Parameter & Unit & RW1 & RW2 & RW3 \\
\hline \multicolumn{5}{c}{ Average value } \\
pH & - & 6.28 & 6.68 & 7.03 \\
Conductivity & $\mu \mathrm{S} / \mathrm{cm}$ & 28.20 & 27.01 & 104.30 \\
Color & $\mathrm{mg} \mathrm{Pt} / \mathrm{L}$ & 12 & 16 & 49 \\
Turbidity & $\mathrm{NTU}$ & 6 & 4 & 12 \\
COD & $\mathrm{mg} / \mathrm{L}$ & 63 & 222 & 275 \\
Absorbance $\mathbf{U V}_{\mathbf{2 5 4}}$ & $1 / \mathrm{cm}$ & 0.09 & 0.15 & - \\
TOC & $\mathrm{mg} / \mathrm{L}$ & 9.10 & 6.03 & 50.49 \\
TC & $\mathrm{mg} / \mathrm{L}$ & 11.38 & 10.50 & 61.58 \\
IC $^{-}$ & $\mathrm{mg} / \mathrm{L}$ & 4.66 & 4.48 & 11.10 \\
NH4 $^{-}$ & $\mathrm{mg} / \mathrm{L}$ & 0.12 & 0.17 & 0.19 \\
$\mathbf{N}^{-} \mathbf{N O}_{\mathbf{3}}{ }^{-}$ & $\mathrm{mg} / \mathrm{L}$ & 1.1 & 1.5 & 1.3 \\
P-PO $^{{ }^{3-}}$ & $\mathrm{mg} / \mathrm{L}$ & $<1.0$ & $<1.0$ & $<1.0$ \\
\hline
\end{tabular}

Poland). Microbiological analysis including coliform bacteria, total number of microorganisms at $22 \pm 2{ }^{\circ} \mathrm{C}$ after 72 h, Escherichia coli, and Enterococci was conducted by an external accredited lab according to ISO methods.

\subsection{Apparatus}

Ultrafiltration was carried out in a laboratory-scale cross-flow configuration equipped with a plate-andframe membrane module SEPA CF-NP (GE Osmonics, Minnetonka, USA) as seen in Fig. 1. Before each experiment, the clean water flux was determined using ultrapure water. A commercial, flat ultrafiltration membrane with the PW symbol was used, made of polyethersulfone with a molar mass limit of $10 \mathrm{kDa}$. Membrane thickness was $0.12 \mathrm{~mm}$ and contact angle was $60^{\circ}$. The contact angle is a measure of hydrophilic/hydrophobic properties. It was measured with a goniometer. The process was operated at a constant pressure of 5 bar and a constant temperature of $22 \pm 1{ }^{\circ} \mathrm{C}$ and constant velocity of $1 \mathrm{~m} / \mathrm{s}$. The volume of the tank is $20 \mathrm{~L}$. In order to determine the efficiency of the ultrafiltration process, rainwater was collected $300 \mathrm{~mL}$ each and a physicochemical analysis was carried out. The process was carried out with a water recovery of $75 \%$, due to the design of the reservoir (Kamińska \& Marszałek, 2020).

\subsection{Membrane Fouling Characterization}

The ultrafiltration process was carried out for $5 \mathrm{~h}$ for each type of rainwater. Each filtration run consisted of five cycles including $60 \mathrm{~min}$ of filtration followed by forward flushing with ultrapure water for $60 \mathrm{~s}$. The volume of permeate was monitored in order to determine the permeability from the following equation:

$L p=V /(\Delta p \cdot A \cdot t)$

where $L_{p}$ is permeability $\left(\mathrm{L} \cdot \mathrm{m}^{-2} \cdot \mathrm{h}^{-1} \cdot \mathrm{bar}^{-1}\right), V$ is permeate volume $(\mathrm{L}), A$ is membrane surface area $\left(\mathrm{m}^{2}\right), t$ is permeate time collection (h), and $\Delta p$ is transmembrane pressure (bar).

Ultrafiltration tests made it possible to calculate the degree of rainwater recovery:

$S=V p / V n * 100 \%$ 

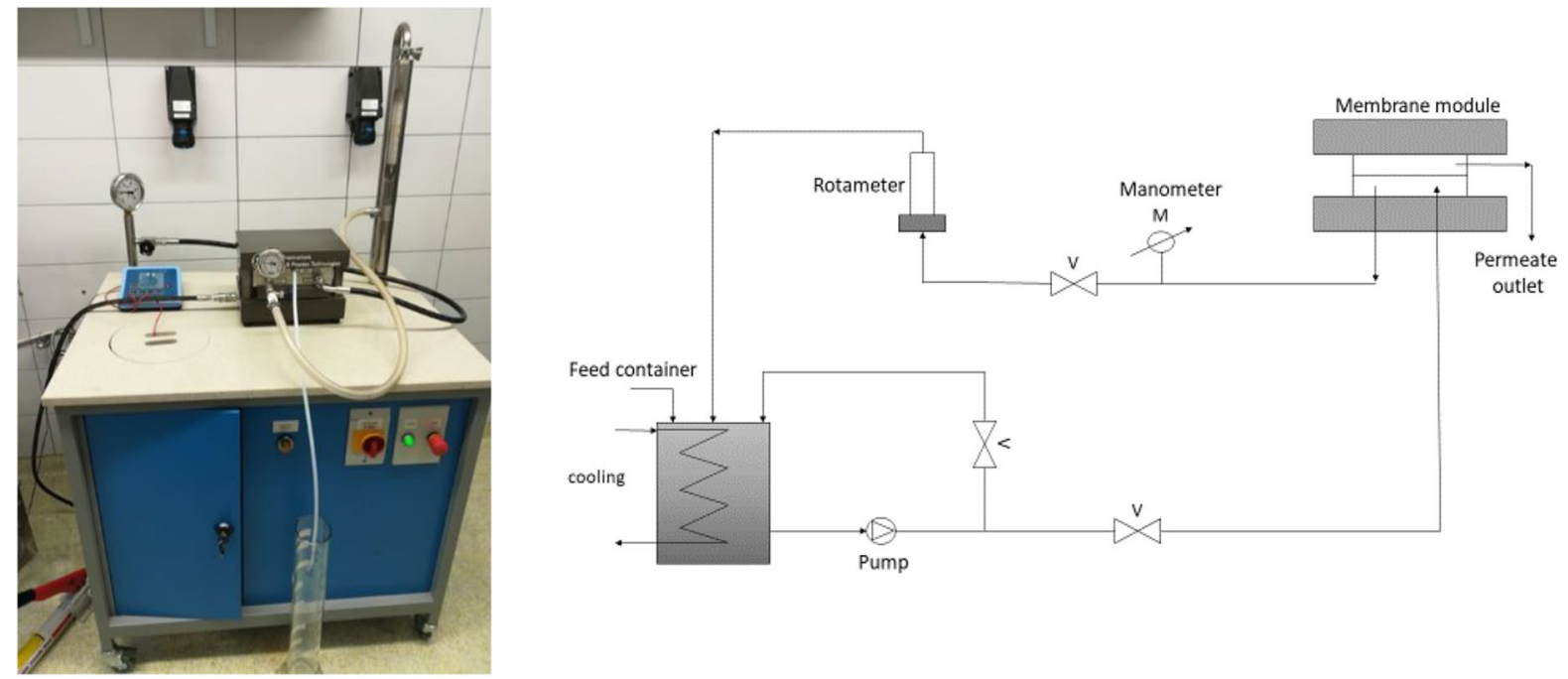

Fig. 1 Schematic diagram of cross-flow filtration set-up

where $V_{p}$-volume of filtered rainwater/permeate and $V_{n}$-volume of rainwater supplied/feed.

In this study, hydraulic resistances were used to characterize the fouling behavior of ultrafiltration membranes when treating rainwater. Hydraulic resistances of membranes and the fouling layer were calculated using the resistance in series model and Darcy's law using the correlations as shown below (Müller et al., 2019).

$k t o t=k m+k f$

$k f=k i r r+k r e v$

$J=\Delta p /(\mu \cdot k)$

where $k$ is hydraulic resistance, where subscripts $m, f, i r r, r e v$, and tot are related to membrane, fouling, hydraulically irreversible fouling, hydraulically reversible fouling, and total fouling $\left(\mathrm{m}^{-1}\right)$, respectively; $J$ is the flux $\left(\mathrm{m}^{3} \cdot \mathrm{m}^{-2} \cdot \mathrm{s}^{-1}\right) ; \Delta p$ is the transmembrane pressure $\left(\mathrm{kg} \cdot \mathrm{s}^{-2} \cdot \mathrm{m}^{-1}\right)$; and $\mu$ is the dynamic viscosity of water at given temperature $\left(\mathrm{kg} \cdot \mathrm{m}^{-1} \cdot \mathrm{s}^{-1}\right)$. Membrane resistance $\left(k_{m}\right)$ was measured for the clean membrane with ultrapure water prior to feed water filtration. Hydraulically irreversible fouling was determined from the flux after forward flushing, while hydraulically reversible fouling was determined from the difference in fouling and irreversible resistances (Müller et al., 2019).

\subsection{Photolytic Oxidation}

The irradiation of the rainwater was performed in a Heraeus laboratory bath reactor (volume of $700 \mathrm{~mL}$ ). The reactor was optionally equipped with an immersed medium-pressure UV lamp of power $150 \mathrm{~W}$. In order to ensure a constant temperature of the reaction mixture of $20 \pm 1{ }^{\circ} \mathrm{C}$, the UV lamp was placed in a glass cooling jacket. The cooling agent was tap water. The reactor was placed on a magnetic stirrer, and samples for analyses were taken after 10, 30, and 60 min of constant UV irradiation. The radiation emitted by the lamp was in the wavelength range from 313 to 578. Table 2 shows the energy of light, which reached the water matrix. The energy of light was calculated based on the multiplication of the Planck's constant with the frequency of light (Kudlek, 2020).

Each experiment was performed in three times, and the mean value was computed to ensure quality assurance. The data obtained in this study are presented as means. 
Table 2 Energy values of individual wavelengths emitted by the UV lamp (Kudlek, 2020)

\begin{tabular}{|c|c|c|c|c|c|c|c|c|c|c|c|c|c|}
\hline Wavelength, nm & 297 & 302 & 313 & 366 & 390 & 405 & 406 & 407 & 408 & 436 & 492 & 546 & 578 \\
\hline nergy of & 4.17 & 4.11 & 3.96 & 3.71 & 3.39 & 3.18 & 3.06 & 3.05 & 3.04 & 2.84 & 2.52 & 2.27 & 2.15 \\
\hline
\end{tabular}

\section{Results and Discussion}

\subsection{Rainwater Treatment by Ultrafiltration}

The ultrafiltration process can reduce turbidity and bacteria to very low levels, but problems such as low removal of dissolved organic matter and low permeate flow can occur. The efficacy depends on the concentrations of various pollutants in rainwater. Rainwater collected from three different roof coverings located in different places was treated by ultrafiltration. Initial research on ultrafiltration of rainwater was presented in Ecesociety.com, proceedings-of-ecopole-peco, 2019. Based on the preliminary results obtained, an ultrafiltration membrane with appropriate efficiency was selected. Then, tests were conducted in the crossflow system. Table 3 presents the values of physicochemical parameters before and after the ultrafiltration process.

As expected, significant reductions in individual parameters were recorded. The turbidity in the ultrafiltration process was completely removed. COD of rainwater decreased in RW1 by $59 \%$, in RW 2 by $69 \%$, and in RW3 by $74 \%$ in the last cycle of the process. In the case of TOC, the ultrafiltration process showed only $18 \%$ removal. However, it should be noted that TOC in raw water was $5.29 \mathrm{mg} / \mathrm{L}$, much less than the highest allowable content of total organic carbon in wastewater discharged into water or soil $(30 \mathrm{mg} / \mathrm{L})$ (Regulation of the Minister of the Environment of 18 November, 2014 on the conditions to be met when discharging sewage into water or soil, \& on substances particularly harmful to the aquatic environment 2014). Unacceptable changes occur when the difference between the highest and the lowest value of TOC per year is greater than $40 \%$ of the minimum value (Regulation of the Minister of the Environment of 18 November, 2014 on the conditions to be met when discharging sewage into water or soil, $\&$ on substances particularly harmful to the aquatic environment 2014). A significant decrease in color was also observed. Water RW1 was characterized by a low concentration of color compared to water from shingle and tar paper. Rainwater from the tar paper was the most polluted, mainly due to the location of the roof. The degree of color loss in the ultrafiltration process in the case of RW3 water was $47 \%$. The results show that the treatment system reduced all tested pollutants below the limits of the Polish guidelines for water that can be reused in accordance with Regulation (EU) 2020/741 of the European Parliament and of the Council of May 25, 2020 (Regulation (EU) 2020/741 of the European Parliament and of the Council of 25 May 2020 on minimum requirements

Table 3 Physicochemical parameters of rainwater

\begin{tabular}{|c|c|c|c|c|c|c|c|c|c|c|c|c|c|}
\hline \multirow[t]{3}{*}{ Parameter } & \multirow[t]{3}{*}{ Unit } & \multicolumn{4}{|l|}{ RW1 } & \multicolumn{4}{|l|}{ RW2 } & \multicolumn{4}{|l|}{ RW3 } \\
\hline & & \multirow[t]{2}{*}{ RW } & \multicolumn{3}{|c|}{ RW after UF } & \multirow[t]{2}{*}{ RW } & \multicolumn{3}{|c|}{ RW after UF } & \multirow[t]{2}{*}{ RW } & \multicolumn{3}{|c|}{ RW after UF } \\
\hline & & & $30^{*}$ & $60^{*}$ & $75^{*}$ & & $30 *$ & $60 *$ & $75^{*}$ & & $30 *$ & $60 *$ & $75^{*}$ \\
\hline pH & - & 7.16 & 7.54 & 7.48 & 7.32 & 5.94 & 7.32 & 7.27 & 7.33 & 6.91 & 7.25 & 7.39 & 7.34 \\
\hline Color & $\mathrm{mg} / \mathrm{L}$ & 23 & 9 & 6 & 6 & 14 & 9 & 7 & 7 & 48 & 25 & 24 & 20 \\
\hline COD & $\mathrm{mg} / \mathrm{L}$ & 59 & 25 & 24 & 24 & 220 & 75 & 69 & 68 & 278 & 82 & 75 & 72 \\
\hline TC & $\mathrm{mg} / \mathrm{L}$ & 3.34 & 2.23 & 2.13 & 1.58 & 3.98 & 2.458 & 2.517 & 2.537 & 57.5 & 48.52 & 49.73 & 51.6 \\
\hline TOC & $\mathrm{mg} / \mathrm{L}$ & 6 & 5.08 & 5.79 & 5.11 & 9.166 & 8.687 & 7.532 & 5.854 & 68.56 & 59.05 & 58.24 & 60.34 \\
\hline IC & $\mathrm{mg} / \mathrm{L}$ & 5.66 & 4.85 & 3.66 & 3.53 & 5.181 & 5.129 & 5.015 & 4.246 & 11.06 & 10.53 & 8.5 & 8.74 \\
\hline
\end{tabular}

*Rainwater recovery 
for water reuse 2020). For example, Kudlek (Kudlek, 2020) also reports that in the rainwater microfiltration system, the coefficients of turbidity removal, COD, $\mathrm{NH}_{3}-\mathrm{N}$, DOC, coliforms, and E. coli were 92.2\%, $65.5 \%, 42.6 \%, 76.9 \%, 96.9 \%$, and $95.5 \%$, respectively. Rainwater filtration could be carried out for 60 days without backwashing, and the permeate flux stabilized at $\sim 22-45 \mathrm{~L} / \mathrm{m}^{2} \cdot \mathrm{h}$ at a constant water pressure of $20 \mathrm{kPa}$ (Shiguang et al., 2021). Teixeira and Ghisi (Teixeira \& Ghisi, 2019) assessed the performance of granular and membrane filters. In both cases, they achieved high levels of pollution reduction. In the case of the sand filter, their removal efficiencies were $13 \%$ for turbidity, $34 \%$ for ammoniacal nitrogen, and $10 \%$ for nitrate. For the membrane filter, the respective values were $11.0 \%, 32.1 \%$, and $13.6 \%$. In turn, Naddeo et al. (Naddeo et al., 2013) proposed a treatment system combining the filtration process with the activated carbon adsorption stage and the UV disinfection stage in one compact device, in which they also obtained high purification efficiency.

\subsection{Membrane Permeability and Fouling Behavior in Ultrafiltration}

The membrane permeability for deionized water was $38.4 \mathrm{~L} / \mathrm{m}^{2} \cdot \mathrm{h} \cdot$ bar. The difference between the water permeate streams from RW1 and RW3 was 16\%. It was found that the permeate flux was maintained at a stable level. In the case of RW1 water, the membrane permeability decreased to $35 \mathrm{~L} / \mathrm{m}^{2} \cdot \mathrm{h} \cdot \mathrm{bar}$, and in the case of RW2 water, $33.4 \mathrm{~L} / \mathrm{m}^{2} \cdot h \cdot b a r$ (Fig. 2). The permeability for RW3 was $28.4 \mathrm{~L} / \mathrm{m}^{2} \cdot \mathrm{h} \cdot$ bar. Because the concentration of organic pollutants expressed as
COD for RW3 water was $80 \%$ higher than for RW1 water, the pollutant concentration in the influent had little effect on the permeate flux. We note that the ultrafiltration process should be run over a longer period of time to fully define the performance of the membrane. Robinson and Bérubé (Robinson \& Bérubé, 2020) report that ultrafiltration membrane performance decreases after 5 years of operation with backwash and chemical cleaning. Membranes treated with a high dose of hypochlorite age the most intensively. Keucken et al. (Keucken et al., 2016) found no changes in the performance of the ultrafiltration polyethersulfone membrane (PES) for a period of 1 year during wastewater treatment. They also concluded that it was too short a period of time for a complete evaluation. He et al. (He et al., 2014) observed a decrease in the permeability of a PVDF membrane purifying drinking water within 3 years.

In order to investigate permeability further, the hydraulically reversible and hydraulically irreversible resistances were calculated. As seen in Fig. 3, total fouling (sum of reversible and irreversible resistances) was higher for RW3.

The advantage of irreversible fouling (65\%) was observed in the case of rainwater RW3, which was characterized by the highest concentration of organic compounds. The PES membrane angle originally was $60^{\circ}$, whereas after the process it increased by $7^{\circ}$. This effect was probably caused by sorption of hydrophobic substances on the membrane surface, as explained in the research of $\mathrm{Chu}$ et al. (Chu et al., 2015) concerning the irreversible fouling of the membrane exceeding the critical irreversibility flux in the pilot water treatment.
Fig. 2 Permeability loss as a function of time of UF for different rainwater

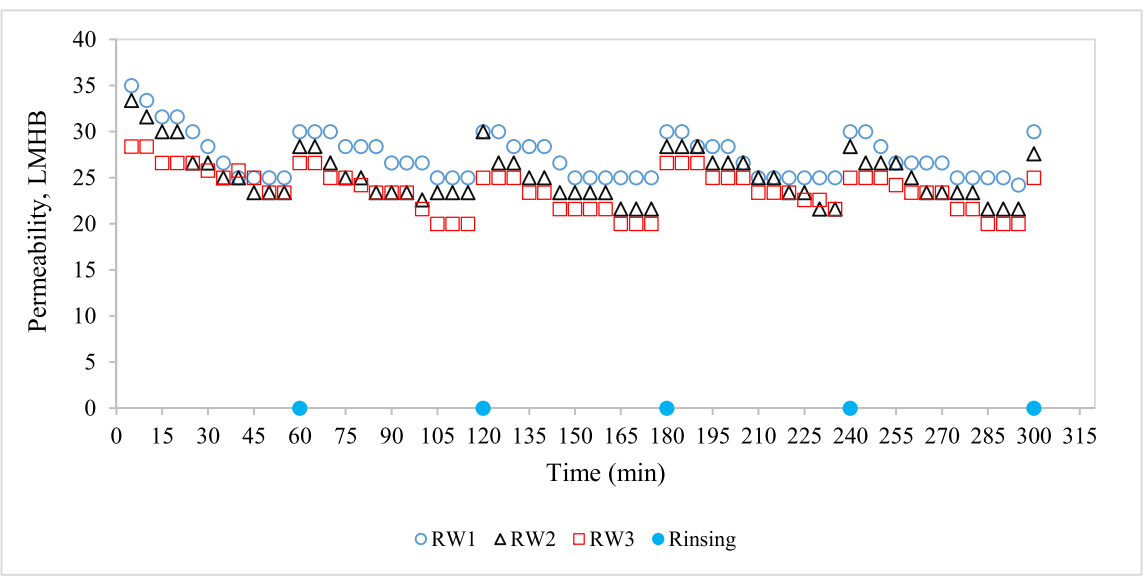


Fig. 3 Irreversible and reversible fouling resistances of ultrafiltration. Each bar corresponds to filtration cycle $1-5$ (kf irr and $\mathrm{kf}$ rev are irreversible and reversible resistances, respectively)

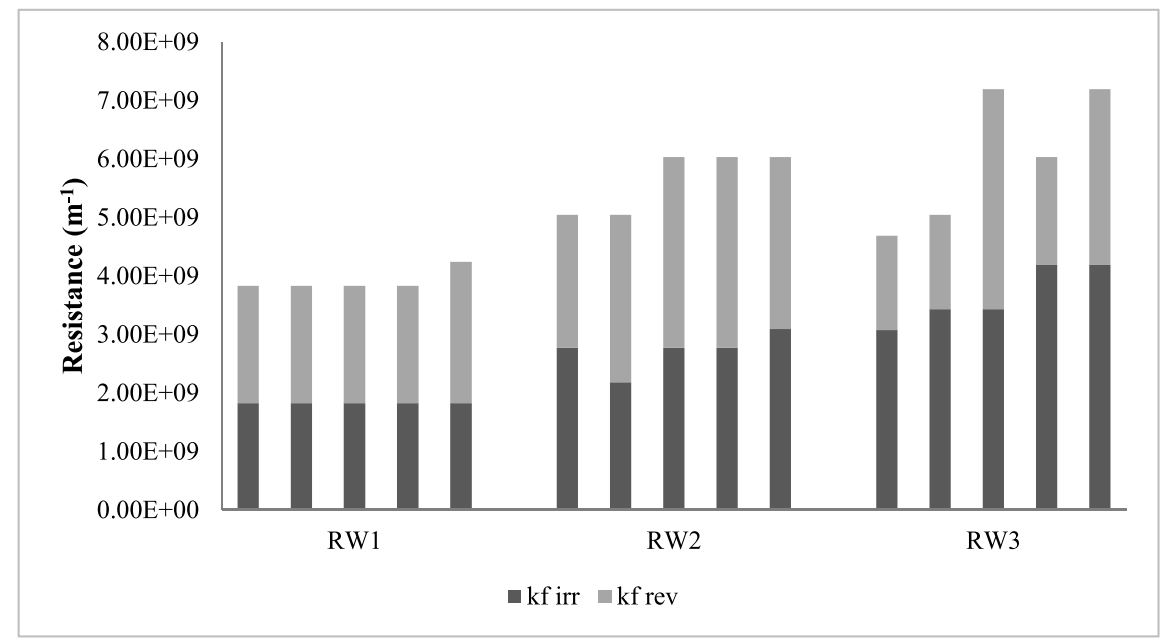

The reversible fouling for RW1 and RW2 was slightly higher, $65 \%$ and $55 \%$, respectively. Ding et al. (Ding et al., 2017) also showed a high share of reversible fouling (90\%) and stable operation of the gravity driven membrane filtration system. Sandoval et al. (Sandoval et al., 2019) investigated ultrafiltration of rainwater from a parking lot. Despite the high degree of contamination of the rainwater, the permeate flux was kept at a stable level using the membrane backwash.

\subsection{Microbiological Quality of Rainwater}

After the rainwater ultrafiltration process, the water was disinfected with UV radiation for $30 \mathrm{~min}$. This duration was the most effective in terms of reduction of the concentration of TOC, color, and turbidity. Rainwater RW1 was used for this process due to the high purification efficiency in the UF process and the higher volumetric flow of purified water and the smallest irreversible fouling. The disinfection efficiency of the pre-treated rainwater was assessed based on the microbiological analysis presented in Table 4.

On the basis of the Regulation of the Minister of Health (Regulation of the Minister of the Environment of 18 November, 2014 on the conditions to be met when discharging sewage into water or soil, $\&$ on substances particularly harmful to the aquatic environment 2014), the quality of water for human consumption is regulated by E. coli and Enterococci; additional requirements include coliform bacteria and the total number of microorganisms. Based on

Table 4 Microbiological analysis of rainwater before and after the UF and UV process

\begin{tabular}{|c|c|c|c|c|c|}
\hline \multirow[t]{2}{*}{ Parameter } & \multirow[t]{2}{*}{ Unit } & \multicolumn{4}{|l|}{ Results } \\
\hline & & RW1 & UV & UF & UF and UV \\
\hline Coliform bacteria & CFU/100 mL & $>200$ & $2 \pm[0 ; 8]$ & 0 & 0 \\
\hline Escherichia coli & CFU/100 mL & $145 \pm[107 ; 195]$ & 0 & 0 & 0 \\
\hline Enterococci & $\mathrm{CFU} / 100 \mathrm{~mL}$ & 0 & 0 & 0 & 0 \\
\hline $\begin{array}{l}\text { Total number of microorganisms at } \\
22 \pm 2{ }^{\circ} \mathrm{C} \text { after } 72 \mathrm{~h}\end{array}$ & $\mathrm{CFU} / 1 \mathrm{~mL}$ & $>300$ & $>300$ & $>300$ & 0 \\
\hline
\end{tabular}

Notes: The number after the given result after the symbol \pm represents the expanded uncertainty calculated for the coverage factor $k=2$, which corresponds to a confidence interval of approximately $95 \%$. For microbiology, the confidence interval of the obtained result was given in accordance with PKN-ISO/TS 19,036: 2011

The value given does not take into account the uncertainty associated with sampling

The sign " $>$ " indicates that the test result is above the laboratory's upper measuring range 
the microbiological analyses performed, it was found that the UF membranes are capable of retaining bacteria and viruses. The ultrafiltration process ensured the complete retention of the coliform bacteria and E. coli. In contrast, it was observed that the number of microorganisms was not reduced. This may be due primarily to imperfections in the membranes and membrane modules and the secondary development of microorganisms in the drainage water from the membrane module. Commercial membranes have discontinuities in the epidermal layer through which microorganisms can penetrate, and the design of modules requiring the feed stream to be sealed from the permeate stream is not always appropriate. Moreover, the literature on the subject proves that the cells of microorganisms can penetrate the pores of the membrane with diameters much smaller than the dimensions of the cells themselves, thanks to pressure deformation with filtering out the intracellular fluid, while the tone of the cell membrane remains unchanged (Krzeminski et al., 2020). Photooxidation also did not result in total elimination of coliform bacteria. It was concluded that bacteria regrowth may take place under optimal environmental conditions (Rizzo, 2009). On the other hand, a complete reduction of microorganisms was demonstrated when the ultrafiltration process and UV radiation disinfection were combined.

\section{Conclusions}

1. It was found that the degree of contamination of the rainwater was dependent on the roof material.

2. As expected, a significant reduction in individual parameters was recorded. The turbidity in the ultrafiltration process was completely removed. COD of rainwater decreased in RW1 by $59 \%$, in RW 2 by $69 \%$, and in RW3 by $74 \%$. It was found that the concentration of pollutants in the inflow had little effect on the efficiency of the ultrafiltration process. The permeate flux was kept at a stable level using the membrane backwash.

3. The ultrafiltration process ensured the complete retention of the coliform bacteria and E. coli. Complete reduction of microorganisms was demonstrated when the ultrafiltration process and UV radiation disinfection were combined.
4. Rainwater collected from the roof and treated in the UF process is an excellent alternative for nonpotable applications. These results show that for this purpose the rainwater can be treated in a single process with little maintenance.

Funding This research was funded by the Polish Ministry of Science and Higher Education.

Data Availability The datasets generated and analyzed during the current study are available from the corresponding author on reasonable request.

\section{Declarations}

Conflict of Interest The authors declare no competing interests.

Open Access This article is licensed under a Creative Commons Attribution 4.0 International License, which permits use, sharing, adaptation, distribution and reproduction in any medium or format, as long as you give appropriate credit to the original author(s) and the source, provide a link to the Creative Commons licence, and indicate if changes were made. The images or other third party material in this article are included in the article's Creative Commons licence, unless indicated otherwise in a credit line to the material. If material is not included in the article's Creative Commons licence and your intended use is not permitted by statutory regulation or exceeds the permitted use, you will need to obtain permission directly from the copyright holder. To view a copy of this licence, visit http://creativecommons.org/licenses/by/4.0/.

\section{References}

Ahmed, W., Hamilton, K., Toze, S., Cook, S., \& Page, D. (2019). A review on microbial contaminants in stormwater runoff and outfalls: Potential health risks and mitigation strategies. Science of the Total Environment, 692, 1304-1321.

Alim, M. A., Rahman, A., Tao, Z., Samali, B., Khan, M. M., \& Shirin, S. (2020). Suitability of roof harvested rainwater for potential potable water production: A scoping review. Journal of Cleaner Production, 248, 119226.

Alim, M. A., Ali Ashraf, A. F. M., Rahman, A., Tao, Z., Roy, R., Khan, M. M., \& Shirin, S. (2021). Experimental investigation of an integrated rainwater harvesting unit for drinking water production at the household level. Journal of Water Process Engineering, 44, 102318.

Bodzek, M., Konieczny, K., \& Rajca, M. (2019). Membranes in water and wastewater disinfection - Review. Archives of Environmental Protection, 45(1), 3-18. https://doi.org/10. 24425/aep.2019.126419. 
Chu, K. H., Yoo, S. S., Yoon, Y., \& Ko, K. B. (2015). Specific investigation of irreversible membrane fouling in excess of critical flux for irreversibility: A pilot-scale operation for water treatment. Separation and Purification Technology, 151, 147-154.

Ding, A., Wang, J., Lin, D., Tang, X., Cheng, X., Wang, H., Bai, L., Li, G., \& Liang, H. (2017). A low pressure gravity-driven membrane filtration (GDM) system for rainwater recycling: Flux stabilization and removal performance. Chemosphere, 172, 21-28.

Ecesociety.com/proceedings-of-ecopole-peco/

Evans, C. A., Coombes, P. J., \& Dunstan, R. H. (2006). Wind, rain and bacteria: The effect of weather on the microbial composition of roof-harvested rainwater. Water Research, 40, 37-44.

He, Y., Sharma, J., Bogati, R., Liao, B. Q., Goodwin, C., \& Marshall, K. (2014). Impacts of aging and chemical cleaning on the properties and performance of ultrafiltration membranes in potable water treatment. Separation Science and Technology, 49, 1317-1325.

Kamińska, G., \& Marszałek, A. (2020). Advanced treatment of real grey water by SBR followed by ultrafiltration-performance and fouling behavior. Water, 154, 12 .

Keucken, A., Wang, Y., Tng, K. H., Leslie, G. L., Persson, K. M., Köhler, S. J., \& Spanjer, T. (2016). Evaluation of novel hollow fibre membranes for NOM removal by advanced membrane autopsy. Water Supply, 16(3), 628-640.

Krzeminski, P., Feys, E., d'Auriac, M. A., Wennberg, A. Ch., Umar, M., Schwermer, C. U., \& Uhl, W. (2020). Combined membrane filtration and $265 \mathrm{~nm}$ UV irradiation for effective removal of cell free antibiotic resistance genes from feed water and concentrate. Journal of Membrane Science, 598, 117676.

Kudlek, E. (2020). Transformation of contaminants of emerging concern (CECs) during UV-catalyzed processes assisted by chlorine. Catalysts, 10(12), 1432.

Li, X., Cai, M., Wang, L., Niu, F., Yang, D., \& Zhang, G. (2019). Evaluation survey of microbial disinfection methods in UV-LED water treatment systems. Science of the Total Environment, 659, 1415-1427.

Liu, X., Ren, Z., Ngo, H. H., He, X., Desmond, P., \& Ding, A. (2021). Membrane technology for rainwater treatment and reuse: A mini review, Water. Cycle, 2, 51-63.

Mendez, C. B., Klenzendorf, J. B., Afshar, B. R., Simmons, M. T., Barrett, M. E., Kinney, K. A., \& Kirisits, M. J. (2011). The effect of roofing material on the quality of harvested rainwater. Water Research, 45(5), 2049-2059.
Müller, A., Österlund, H., Nordqvist, K., Marsalek, J., \& Viklander, M. (2019). Building surface materials as sources of micropollutants in building runoff: A pilot study. Science of The Total Environment, 659(1), 1415-1427.

Naddeo, V., Scannapieco, D., \& Belgiorno, V. (2013). Enhanced drinking water supply through harvested rainwater treatment. Journal of Hydrology, 498(19), 287-291.

Pavolová, H., Bakalár, T., Kudelas, D., \& Puškárová, P. (2019). Environmental and economic assessment of rainwater application in households. Journal of Cleaner Production, 209, 1119-1125.

Regulation (EU) 2020/741 of the European Parliament and of the Council of 25 May 2020 on minimum requirements for water reuse.

Regulation of the Minister of the Environment of 18 November 2014 on the conditions to be met when discharging sewage into water or soil, and on substances particularly harmful to the aquatic environment.

Rizzo, L. (2009). Inactivation and injury of total coliform bacteria after primary disinfection of drinking. Journal of Hazardous Materials, 165(1-3), 48-51.

Robinson, S., \& Bérubé, P. R. (2020). Membrane ageing in full-scale water treatment plants. Water Research, 169(1), 115212.

Sandoval, A. D. O., Brião, V. B., Cartana, V. M., Hemkemeier, F. A., \& Friedrich, M. T. (2019). Stormwater management by microfiltration and ultrafiltration treatment. Journal of Water Process Engineering, 30, 100453.

Shiguang, Ch., Hongwei, S., \& Qiuli, Ch. (2021). Performance of an innovative gravity-driven micro-filtration technology for roof rainwater treatment. Environmental Engineering Research, 26(6), 200450.

Teixeira, C. A., \& Ghisi, E. (2019). Comparative analysis of granular and membrane filters for rainwater treatment. Water, 11, 1004.

The Act of 18 July 2001 - "Water Law" (Acts. Laws of 2005 No. 130, item. 1087).

Zhang, Q., Wang, X., Hou, P., Wan, W., Li, R., Ren, Y., \& Ouyang, Z. (2014). Quality and seasonal variation of rainwater harvested from concrete, asphalt, ceramic tile and green roofs in Chongqing, China. Journal of Environmental Management, 132, 178-187.

Publisher's Note Springer Nature remains neutral with regard to jurisdictional claims in published maps and institutional affiliations. 